\title{
ОРЧИН УЕИЙН ТӨВ АЗИЙН МАЛ АЖ АХУЙ: МАЛЫН ТУХАЙ АРДЫН УЛАМЖЛАЛТ МЭДЛЭГ
}

М.Хурметхан ${ }^{*}$

\section{Товч утга}

7 өв Азийн мал, мал аж ахуй, мал маппах арга технопоги, ашиг шим болон орчин уеийн байдпыг тусган

1 харуупсан.

Түлхуүр үг: Төв ази, мап аж ахуй, орчин уе

\section{Туркменистаны мап аж ахуй}

БНТуркменистан упс нь Дундад Азийн баруун өмнөд хэсэГт оршдог. Газар нутгийн хэмжээ 488.2 мянган км.кв. Хүн ам нь $4688963 / 2007 /$. Хойд талаараа Казахстан, хойд болон зүүн талаараа Узбекстан, өмнөд талаараа Афганистан, Ирантай хил залган оршдог. Нутгийн ихэнх нь тап, 4/5 нь Тураны хонхорт оршдог. Хамгийн гол байгалийн баялаг нь газрын тос, байгалийн хий. Зун халуун, хуурай, өвөл дулаан, хавар их богино боловч бороо ихтэй, намар нь хуурай болдог онцлогтой. Нутгийн 80\%а газрын гадаргуун болон тогтмол урсгал ус үгүй. Туркменистан үндсэндээ каракуль хонийг өсгөдөг. 1976 онд Туркменистанд үхэр 531.6 мян. толгой, гахай 121.7 мян толгой, хонь ямаа 4423.3 мян толгой, 13.2 мян толгой адуу, 88.1 мян толгой тэмээ байв. Баян бүрдүудэд мал аж ахуй сайн хөгжсөн байдаг.

Туркменистан тусгаар тогтнолоо зарласны дараа хөдөө аж ахуйн бүтээгдэхүун 1980-аад оныхоос буурав. Мал аж ахуйд каракуль хонь үржүупэх, ямаа, адуу, тэмээ чухал үүрэгтэй. 1996 онд Туркменстанд 111.2 мян тонн мах, 754.8 тонн суу үйлдвэрлэж, нэг хүнд 24.2кг мах /хэрэгцээ 42kг/, 164кг сүу / ээрэгцээ 185кг/ байв.

"М.Хурметхан- Олон упс судпалын хүрээлэнгийн эрдэм шинжилгээний тэргүүлэх ажилтан доктор (Sc.D), профессор 
1997 онд нийгмийн болон хувийн өмчид 1155.6 мян топгой үхэр, /1991онд 829мян толгой/, 6138.2мян толгой хонь ямаа /5477мян топгой/, 105.6 мян толгой тэмээ /86.7мян/ байв. Мал аж ахуйд хонин аж ахуй давамгайлж, хөдөо аж ахуйн нийт бүтээгдэхүүний 70\%-ийг дангаараа өгнө. Каракупь бопон сараджин чүпдрийн хонь өсгөдөг. Сүүпийн 10 жипд хонины тоо $33 \%$ өсч, хонины мах $57 \%$, арьс $22 \%$ нэмэгджээ.

\section{Узбекстаны мап аж ахуй}

БНУзбекстан упсын газар нутгийн хэмжээ 447.1 мянган км.кв. Хүн ам нь $25563441 / 2002 /$. Газар нутаг нь зуүн-баруун тал хээр, зуүн өмнөд уулархаг хэсэгт хуваагдана. Ховор металл, төмөр, алт зэрэг ашигт малтмап бий. Тэндээс 562 зүйл минерал олджээ. Газрын тос 5 муж нутагт илэрчээ. Узбекстаны мал аж ахуйд каракуль хонь чухал байр эзэлнэ. Бэлчээр ба хадлангийн талбай 21.5 сая га болно. 1974 онд ухэр 3181.7 мян. толгой /үунээс үнээ $1216.4 /$, гахай 329.6, хонь ямаа 8539.1мян толгой байв. Каракупь хонийг Бухара мужид өсгөдөг. 2001 онд Узбекстанд 8.1 сая толгой хонь, 5.3сая толгой үхэр, 830000 топгой ямаа, 89000 толгой гахай, 165000 илжиг, 150000 адуу, 28000 тэмээ, 14 сая орчим тахиа байв. Мөн онд мах үйлдвэрпэл нийт 512000 тонн, түунээм үхрийнх $77 \%$, хониных 17\% гэх мэт байв. 15900 тонн ноос өгчээ. Мон хур хорхой өсгөж, 2000 онд 1200 тонн торго үйлдвэрлэжээ. ${ }^{1}$

\section{Афганистаны мал аж ахуй}

Афганистан Төв Азийн өмнөд хэсэгт оршдог. Өмнөд тапаараа Пакистан, баруун талаараа Иран, зуүн талаараа Тажикстан, Узбекстантай, зүүн хойд тапаараа БНХАУ-тай хиплэнэ. Газар нутгийн хэмжээ 647.5мя км.кв. хүн ам нь 27755775 /2002/. Газар нутгийн 3/4 нь уупархаг. Баруун хойт болон өмнөд хэсэг нь тал хээр. хуурай халуун цаг ууртай. Хур тунадасны хэмжээ 350-800мм. Газрын тос, байгалийн хий, нүурс, төмрийн баялаг ихтэй орон. Уламжлалт мал аж ахуйн орон болно Афганистанд 4.8 сая толгой каракуль хонь үржүүпдэг бөгөөд бүх хонины тоо толгойн $1 / 4$-ийг эзэлнэ. Гэхдээ сүулийн 30 гаруй жилийн турш Афганистаны мал аж ахуйн талаар тодорхой статистик мэдээлэл үгүй юм. Мал аж ахуйд байгал цаг уурын хамт бусад шаптгааны хорогдоп ч ихтэй. Энэ бүхний явцад хүн амын сүү махны хэрэгцээ хангагдахгүй байгаа юм. Нүүдпийн мапчид гопдуу хонь ямаа өсгөх бөгөөд барагшаалбал тэд махны 80\%-ийг эзэмших бөгөөд 20 сая толгой хонь, 3.Зсая ямаатай гэж үздэг. 


\section{Тажикстаны мап аж ахуй}

Тажикстан упс Дундад Азийн өмнөд хэсэгт оршдог. Газар нутаг нь 143.1мян км.кв. Хойд талаараа Узбекстан, Киргизстан, зүун талаараа БНХАУ, өмнөд талаараа Афганистантай хил залгана. Хүн ам нь $6719567 / 2002 /$.

Тажикстаны нутаг уулархаг байдаг. Нуттийн 93\% нь ТияньШань, Гиссар Алай, Памирын уулсад байрлана. Нуттийн 1/2 нь далайн түвшингээс 3000м өндөрт оршино. Эх газрын эрс тэс уур амьсгаптай. Усны нөөцеөр баяпаг орон юм. 1975 онд 1089.6 мян толгой үхэр, Үүнээс 397.4 мян топгой үнээ, 2334.0 мян толгой хонь, 526.7 мян толгой ямаа, 41.4 мян топгой адуутай байв.

\section{Оросын Хопбооны Упс}

Европын дорнод хэсэг.

Нутаг дэвсгэр-17075.44

Хүн ам-148.6 сая /1993/

Нийспэл-Москва

Нутгийн Европын хэсэг нь талархаг, Уралын нуруунаас Саян, Байгапд өвөр Байгалийн уулс, Сибирийн тарамцаг уулстай. Далайн болон эх газрын эрс тэс, муссоны уур амьсгалын өөрчлөлттэй. 1-р сарын дундаж температур нь 1-50с, 7-р сарынх 1-25с, жилд 1001000 мм хүртэл тундас унадаг. Нефть шатах хий, чупуун нуурс, төмрийн хүдэр, үнэт, өнгөт төмөрлөг, фосфор, калийн давс, алмаз зэрэг олон торлийн ашигт малтмал олборподог. Том үйлдвэруүд нь Москва, Санкт-Петербург, Унгар, Ижип мөрний сав газар, баруун Сибирьт төвпөрчээ. Машин, хими, нефть хими, хуваншар, эрдсийн бордоо, нийлэг мяндас, авто машины дугуй, барипгын матерап, хөнгөн ба хүнсний үйлдвэртэй. Илчит, атомын болон УЦС-тай. Пуужин, сансрын хийгээд цөмийн техникийн сапбар хөгжсөн. Үр тариа, чихрийн манжин, наранцэцэг, төмс, олсны ургамал голпон тарьдаг. Мах сүуний чиглэлийн ухэр, мах ноосны хонь өсгодег. OXУ-ын малын бэлчээр нь 87.3 сая га бөгөөд нутгийн 5\%-ийг эзэлнэ. ОХУ-д 2001 оны байдпаар үхэр-27 294 000, хонь-12 561 000, гахай-15 707 000, адуу -1.6 сая байв. Жилд 1.7 тэрбум ам долпарын мах, махан бүтээгдэхуүн импортпоно.

\section{ОХУ-Ын БНБурнад улс.}

Нутаг дэвсгэр-351.3 мянган кв.км /1989 оны байдпаар/

Хүн ам- 1045.6 мянган хүнтэй.

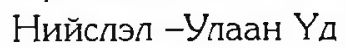


Буриад улс нь Азийн төвд оршино. Өмнөд Сибирийн уупархаг нутагт хамрагдах бөгөөд дэпхийн цэнгэг усны нөөцийн үлэмж хэсгийг хамрах Байгаль нуур оршино. Байгаль нуур нь далайн түвшнээс 456 м өндөр өргөгджээ. Уулархаг газарт унах хур тунадас нь жипдээ 1000-1500мм хүрдэг боловч уулын хөндийд 180300мм тунадас унадаг байна. Ургампын нөмрийг нь уул тайга, мөн ууп тайга нь хээртэй хосопсон бус бий. Үүнээс гадна нуга хээрийн бүс ихээхэн талбай эзэлнэ. Ашигт малтмал арвин, ОХУ-ын цинкийн $48 \%$, свинцийн 27\% нь Буриад оронд байдаг. Усны нөөц арвин 34422 нуур цөөрөм байгаагаас усны нөөц бухий Байгаль нуур нь Дэпхийн хамгийн цэнгэг устай нуур юм.

1996 оны байдлаар 4219.5 мянган га хөдөө аж ахуйн эдэлбэр газар байгаа нь нийт нуттийн $12.6 \%$ болно. Түүний дийлэнх нь бэлчээрийн эдэпбэр юм. Түүнээс гадна ойн талбай их. Нийт нутгийн 26361.0 мянган га буюу нийт нутгй̆н $75 \%$ нь ой мод юм. Ой болон бэлчээрийн эдэлбэрийг малын бэлчээрт ашиглах тул мал эсгэх бололцоо их. Ачийн тойрог болон Саяаны нуруу орчимд хагас нуүдлийн аж ахуйг эрхэлж байна. Харин нийт малаас үхэр зонхилох ба нуудлийн мал аж ахуйг эрхэлж байсан уеийн нутгийн малыг одоо өсгөх сонирхоптой. Ер нь Буриад орон 1940 оноос хойш нуудлийн мал аж ахуйгаас суурин мал аж ахуйд шилжсэн билээ. Дэлхийн 2р дайны үед эрчүуд нь дайнд явснаас өвгөд, хөгшид, эмэгтэйчүүд нуүж чадахгүй малаа суурин хэлбэрээр өсгех болсон байна. Одоо дийлэнх нь суурин хэлбэрийн мал аж ахуйг эрхэлж байна. Буриад улсын малын тоог 1916-2000 он хуртэл хүснэгтэнд үзуүлэв.

ОХУ-ын Буриадын малын тоо (мянган толгой)

\begin{tabular}{|c|c|c|c|c|}
\hline Он & Үхэр & Үунээс үнээ & Бог мал & Алуу \\
\hline 1916 & 411 & 196 & 394 & - \\
\hline 1923 & 365 & 156 & 233 & 147 \\
\hline 1941 & 414 & 160 & 530 & 140 \\
\hline 1950 & 389 & 137 & 587 & 95 \\
\hline 1960 & 370 & 137 & 1482 & 67 \\
\hline 1970 & 440 & 160 & 1706 & 57 \\
\hline 1980 & 502 & 175 & 1910 & 56 \\
\hline 1990 & 560 & 180 & 1493 & 68 \\
\hline 1994 & 455 & 177 & 822 & 73 \\
\hline 1995 & 425 & 171 & 623 & 72 \\
\hline
\end{tabular}




\begin{tabular}{|l|l|l|l|l|}
\hline 1996 & 397 & 162 & 455 & 68 \\
\hline 1997 & 358 & 149 & 288 & 62 \\
\hline 1998 & 347 & 147 & 294 & 57 \\
\hline 1999 & 330 & 143 & 233 & 50 \\
\hline 2000 & 355 & 150 & 254 & 51 \\
\hline
\end{tabular}

XX -p зууны 90-ээд онд хөдөө аж ахуйн цаг агаарын тааламжгүй байдлын улмаас унаптад оров.1992-93 онд нийгмийн хэвшилд малын тоо 20\%-иар хорогдсон байна². Буриадын хөдөө аж ахуйд мал аж ахуй, газар тариапан, хунсний ногоо давамгайлна. Мах үйлдвэрлэл 2005 онд 52.52 мян.т (2004 онд-50.11мян.т) болов. Сүүний үйлдвэрпэл 225.92 мян.т (2004 онд 225.69 мян.т) болов.

OXУ-ын Тува улс: Тува нь 175.5 мян.км нутагтай. 310.0 мянган хүн амтай. Нийт хүн амын 67\% нь Тува үндэстэн. Баруун, Төвийн район нь уулархаг, ойт хээрийн бус давамгайлна. Нуудлийн мал аж ахуй зонхилсон бог мал, ухэр зонхилсон. Ойролцоогоор нэг сая маптай. Бог мап зонхилсон болохоор нүудпийн хэлбэрийг тэр мал п тодорхойлно. Зун цагт бүх мал бэлчээрт, харин өвлийн упирапд хашаа саравчинд малаа оруулж, хагас тэжээпийн хэлбэрээр малпана. Адуу мал аж ахуйд ихээхэн Уүрэгтэй, түуний зэрэгцээ морин тэрэг, чаргыг ердийн хөсөгт өргөн ашигпана.

1918-1944 оны хооронд Тувагийн ерөнхий дүр төрх дараах байдалтай байлаа. ${ }^{3}$

\begin{tabular}{|l|c|c|c|c|}
\hline & 1918 & 1921 & 1931 & 1944 \\
\hline Бүх хүн ам.мян.хүн & 60.6 & 63.0 & 82.2 & 95.0 \\
\hline Үунээс тыва & 48.0 & 50.0 & 64.9 & 80.8 \\
\hline Засаг захиргааны хошуу & 5 & 7 & - & 15 \\
\hline Хот & 1 & 1 & 1 & 1 \\
\hline Тосгон & - & 30 & - & 108 \\
\hline
\end{tabular}

1921-1944 оны Тувагийн хөдөө аж ахуйн байдал ${ }^{4}$

\begin{tabular}{|l|c|c|c|}
\hline & 1921 & 1931 & 1944 \\
\hline Тариалангийн бүх талбай мян.га & 14 & 19.7 & 58.1 \\
\hline Үр тариа & - & 18.6 & - \\
\hline
\end{tabular}


Малын тоо бүх аж ахуйн сапбарт мян.топ

\begin{tabular}{|l|c|c|c|}
\hline Үхэр $^{5}$ & 126 & 168.2 & 166.8 \\
\hline Гахай & 1.2 & 1.3 & 2.5 \\
\hline Хонь,ямаа & 631 & 821.6 & 609 \\
\hline Адуу & - & 105.3 & 68.6 \\
\hline Буга & - & 10.4 & 9.8 \\
\hline
\end{tabular}

Хөдөө аж ахуйн техник (нэгж)

\begin{tabular}{|l|c|c|c|}
\hline Трактор & - & 9 & 42 \\
\hline Комбайн & - & - & 2 \\
\hline Ачааны машин & - & - & 11 \\
\hline
\end{tabular}

\section{Тувагийн хүн ам}

\begin{tabular}{|c|c|c|c|}
\hline \multirow{2}{*}{ Он } & \multirow{2}{*}{$\begin{array}{c}\text { Бүх хүн ам мян. } \\
\text { хүн }\end{array}$} & \multicolumn{2}{|c|}{ Уугуул тува } \\
\cline { 3 - 4 } & 63 & Мян.хүн & Хувь \\
\hline 1921 & 82.2 & 64.9 & 79.4 \\
\hline 1931 & 95.4 & 81.8 & 78.9 \\
\hline 1945 & 171.9 & 98 & 85.7 \\
\hline 1959 & 230.9 & 135.2 & 57 \\
\hline 1970 & 267.6 & 161.9 & 58.6 \\
\hline 1979 & 308.5 & 198.4 & 60.5 \\
\hline 1989 & 310.9 & 208.6 & 69.3 \\
\hline 2000 & & & 67.1 \\
\hline
\end{tabular}

Үүнээс узэхэд уугуул хүн ам нь өнгөрсен зуунд 50.0-208.6 мянга болсон нь харагдана. 2000 оны эхний байдлаар бүх хүн ам нь 310.9 мян.хун байсан ба эрэгтэй $48.9 \%$, эмэгтэй $51.1 \%$ байв. Эдийн засгийн сапбарт ажилпагсдын дунд хөдоөд аж ахуйн салбрт ажьилпагсад 16.9\%-ийг эзэлж байв. 
Тувагийн аж ахуйн бүх сапбарын мапын тоо (жилийн энэс,Мян.топ) ${ }^{5}$

\begin{tabular}{|l|l|l|l|l|l|l|l|}
\hline & 1945 & 1950 & 1960 & 1970 & 1980 & 1990 & 2000 \\
\hline Үхэр & 143.9 & 102.8 & 137.6 & 194.1 & 161.2 & 205 & 97.2 \\
\hline Үнээ & 64.1 & 46.3 & 54 & 72 & 61.1 & 73.9 & 45.7 \\
\hline Гахай & 2.4 & 4.2 & 26 & 27.2 & 40.3 & 65.2 & 10.9 \\
\hline Хонь,ямаа & 538.5 & 413.1 & 873.4 & 1119 & 1117.6 & 1226.8 & 653 \\
\hline Адуу & 61.6 & 49.5 & 42.3 & 38.5 & 28.1 & 39.6 & 25.1 \\
\hline Буга & 8.1 & 3.1 & 5.8 & 11.6 & 14.5 & 8.1 & 1.2 \\
\hline
\end{tabular}

Эндээс харагдаж байгаачпан малын тоо толгой 1990-2000 онд хорогдсон байдал ажиглагдаж байна. Мөн нэг мапаас авах ашиг шимийн хэмжээ мөн буурчээ. Тухайлбал 1990 онд хөдөө аж ахуйн бүх салбарт 23.6 мян тонн мах (нядапгааны жин) бэптгэж байсан бол 2000 онд 12.3 мян.тонн болжээ ${ }^{6}$. СуҮ 1990 онд 73.4 мян.т байснаа 47.0 мян.т , ноос 2328 т байснаа 750 т болж тус тус буурчээ.

1990 оноос хойш улс төр, эдийн засгийн өөрчпөлт, япангуяа эдийн засаг, зах зээпийн харилцаанд шилххсэн, өмч хувьчлал, үнэ чөлөөпсөн, өмчийн опон хэпбэр уүссэн опон хүчин зуйлийн улмаас Тувагийн эдийн засаг бүхэлдээ уналтанд орж, бүх салбарын үйлдвэрлэл эрс буурч, ард түмний аж байдлын үзүулэлтүүд ихэд бг.рчээ. Харин 1999 оноос эдийн засаг сэргэн хөгжих замд орж эхэлсэн юм. Тувад өмчийн янз бүрийн хэлбэрийн 246 үйлдвэр аж ахуйн газар, түүний дотор 43 том, дунд үйлдвэр ажиплаж байна. 2000 онд 830.2 сая рублийн бүтээгдэхуүн үйлдвэрпэсний $53.8 \%$ ийг нь хувийн сектор эзэпж байв. Аж үйлдвэрийн гоппох сапбар боп түпш, эрчим хүч /нуүрс опборпох/, өнгөт метаппурги /апт олборлолт/, ойн болон мод боловсруулах үйлдвэр, хөнгөн, хүнс, гурил, холимог тэжээлийн үйлдвэр хамаарна. Тувагийн томоохон үйлдвэрийн газрууд боп Каа Хэмийн нүүрсний ил уурхай, Тувагийн нэхий, хивсний комбинат, алтны олборлох артелиуд, оёдпын фабрик, Туваасбест комбинат, Ак-Довуракийн оёдоп нэхмэлийн үйлдвэр юм. 2000 онд Тувагийн аж үйлдвэр нүүрс 522 мян.т, апт - 1143 кг, асбест - 2200 т, зүсмэл матерап 8000 куб.м, гурил 5000т, талх, талхан бутээгдэхуун 27мян.т тус тус үйлдвэрпэжээ.

Тувагийн эдийн засгийн гоп сапбар нь хөдөө аж ахуй бөгөөд 2000 онд 1300 сая (УҮнээс мап аж ахуй 938.7сая) рублийн 
бүтээгдэхүун гаргасны 89\%-ийг иргэд болон хувийн аж ахуйнууд үйлдвэрлэжээ. Түунд 27.6 мянган хувь буюу хөдөлмөрийн насны хүн амын 20 гаруй хувь ажилпадаг. Өмч хувьчлал, газрын шинэтгэл явуулсны үр дүнд ардын аж ахуйтнууд олноор буй болж, эдийн засаг, ялангуяа ХАА-н үйлдвэрлэлд эерэг нөлөө үзуүпэх болпоо.

2001 оны 1-р сарын 1-ний байдлаар тус улс 96.4 мянган үхэр, түүнээс 45.7 мянган үнээ, 10.8 мянган гахай, 651.1 мянган толгой хонь, ямаа, 25 мянган адуу, 1.1 мянган буга, 130 мянган шувуу, 270 тэмээтэй байв.

2000 онд 12.3 мян.тонн мах, 47 мян.тонн сүу, 6.5 сая ш өндөг, 750 тонн ноос үйлдвэрлэжээ. Мөн онд 44.2 мян.га¿ тариалалт хийснээс 29.4 мян.га-д үр тариа тариалж, үр тариа 24.9 мян.тонн, төмс 26.6 мян.тонн, хүнсний ногоо 5.4 мян.тонн хураан авчээ. ОХУ-ын Алтайн БНУ. Алтай нь 11 засаг захиргааны нэгж, 90 хөдөөгийн засаг захиргааг нэгтгэнэ. Газар нутаг нь 92 902 кв.км.бөгөөд ОХУ-ын бүх нутгийн $0.55 \%$ нь бопно. Хөдөө аж ахуйн эдэлбэр газар нь 19\%, ой мод 47\% юм. Нийспэп нь ГорноАлтайск хот. Хөдөө аж ахуйн үйлдвэрлэсэн бүтээгдэхүун нь 2001 онд 1871.3 сая рубль хурчээ. Хөдөо аж ахуйн бүтцэд мал аж ахуй нь 70\%,тариалан 30\%-ийг эзэлнэ. Мал аж ахуй нь бэлчээрийнх бөгөөд өвөрмөц бүтээгдэхүүн өгнө.

Үүнд: -марал бугын аж ахуй нь гадаад валютын гол эх уусвэр болно

- уулын-Алтай үүпдрийн ямааны ноолуур

- бэлчээрийн адууны аж ахуй

- зөгийн аж ахуй зэрэг болно.

\section{БНХАУ-ын Төв Азийн сектор}

БНХАУ-ын байгалийн бүс нь ихээхэн ялгагдах орны нэг юм. Тус орон байгалийн 9 бүсэд хуваагдана. 9.6 сая хавтгай дөрвөлжин км нутаг нь энэ орныг дэлхийн хэмжээнд Орос, Канадын дараах байранд оруулжээ. БНХАУ-ын нутаг нь өрген уудам тул далайн эргийн зөөлөн уур амьсгалын зэрэгцээгээр нуүдпийн мал аж ахуй эрхпзх 5 томоохон район байдаг. Эдгээр районд дэлхийн нүүдлийн мал аж ахуйд тэргүун байранд ордог олон зуйл байдаг тул юуны өмне эдгээр 5 районы байгаль цаг уурын байдаптай товч танилцана.

Мапын байгалийн бэпчээр нь 3.53 сая км2 бөгөөд бүх Хятадын нутгийн 37\%-ийг эзэлнэ. Мал аж ахуйн том нутаг бол Синьзян, Ганьсу, Цинхай, Өвөр Монгол болно. 1976-1980 онд бэлчээрийг 303 сая га өргежүүпэв. Байгалийн олон янзын бүс бүслүүр нь 
нүүдлийн мап аж ахуй упамжлан хөгжиж ирсэн түухийг 70 гаруй сая га бэлчээр, хадлангийн талбай байдаг нь малын тэжээлийн баазын үндэс болж байгаа юм. БНХАУ-ын ХААЯ-аас 10 чухап арга хэмжээ авч явуупж байгаагийн бэпчээрийг зохистой ашиглах, хамгаалах асуудал юм. Энэ нь нүудлийн мал аж ахуйн уламжлапт районуудад ихээхэн тусгалаа олж байна. Үүнд : Умардын байгапийн бэлчээрийн нөөцийг хамгаалах бус, Хөх мөрний дээд урсгал болж Хатан гопын дунд, дээд урсгапын бэлчээрийг хамгаалах бус, Хех нуур, Төвдийн өндөрлөгийн байгалийн бэлчээрийг хамгаалах бүс, Баруун өмнөд нутгийн бэлчээрийг хамгаалан зохистой ашиглах бүс зэрэг 4 төрлийн бүсийг сэргээн байгуулах зорипт тавин ажиллаж байна.

БНХАУ-д хонь 1952 онд 36.9 сая байсан бол 2000 онд 133.2 саяд хүрэв. Хонийг Сяньзян, Өвөр Монгоп, Ганьсу дахь хятад биш үндэстнууд үржүүпнэ. Ямааг сүу болон ноолуурын ашиг шимийн хувьд өсгеж, 1952 онд 24.9 сая байсан бол 2001 онд 157.4 сая хүрэв. Хонь болон ямааны тоо топгой 2001 онд 288 саяд хурэв. 2001 онд 129 сая топгой үхэр /1965 онд 66.6 сая байсан/ ба сарлаг байсан ба адуу 1965 онд 792000 байсанаас 8.8 сая толгойд хурэв. 2001 онд БНХАУ 65.3 сая тонн мах үйлдвэрлэсэн нь дэлхийн мах үйлдвэрлэлийн 27\%-ийг дангаараа эзэлж байлаа.

Өвор Монголын Өертөе Засах Орны мал аж ахуй. ӨМӨЗО нь нийт Хятад орны 12\%-ийг эзлэх нөл, цөлөрхөг хээр, тап, Хянганы уулархаг нутаг зэрэг байгалийн олон бүсийг хамарсан нутагтай. БНХАУ-ын хэмжээнд 2-р байранд орох Шар мөрөн буюу Хатан голоос эхпээд Эржин, Пиан, Нэнжин зэрэг олон том гол мөрөнтэй. Уур амьсгапын хувьд эх газрын болон зөөпөн цаг уурын аль нь ч бий. Жилд 50-500 мм хур тунадас унах нутаг байхын зэрэгцээ Хянганы уупсын орчим түунээс ч их хур тунадас унана. Ойн тапбай нь бүх Хятадын нийт ойн $13.6 \%$-ийг эзэлнэ. Ойн зах нутаг нь малын бэлчээрт ашиглахад тохиромжтой. Ер нь ӨМӨЗО нь бэлчээр нутгаар арвин юм. 8.8 сая га бэлчээр нь 2000 км урт зурвасыг хамрах бөгөөд БНХАУ-ын бэлчээрийн томоохон эзэмшил районд багтдаг байна. Бэлчээр нь опон мянган км урт ургэлжлэх туп байгал цаг уурын олон бусийг төлөөпдөг. Энд ойт хээр, хээр, цөлөрхөг хээр, заримдаа цөл, цөлийн бэлчээр аль аль нь бий. Байгалийн бэлчээрийн арвин нооц нь Шанхын үхэр, адуу, үзэмчин хонь, мухар улаан үхэр, алшаа үхэр, ноолуурын цагаан ямаа зэрэг олон үупдрийн мал өсгөх таатай нохцлийг бүрдүупжээ. ӨМӨЗО-ны Баяннуур аймгийн Пиньхэ хотын цагаан ямааны ноолуур нь ширхэг 
урт, өнгөлөг, бат бэх, уян хатан чанар сайн туп Итали улсад болдог олон улсын үзэсгэлэнгээс алтан медаль хүртэж байжээ. Зөвхөн Баяннуур аймгийн Пиньхэ хотын орчимд 10 сая хонь, ямаа осгөж 5 саяыг нь хэрэглээнд оруупж байна. Пиньхэ хот ойрын жилүүдэд сайн үүлдрийн хонь ямааг сүргийн бүтцэд 80\%-д хүргэж, нэг хонь ямааны нядалгааны цэвэр жинг 20 кг-д хүргэх ноолуурын хэмжээг 300гр-д хүргэх зорилттой ажиллаж байна.

Өвор Монгопд эрт цагаас нааш суурин суусан монгопчууд мал аж ахуйг эрхэлж иржээ. 1947-1957 оны хооронд мал аж ахуйн салбарт ахин гарчээ. "Гурван улаан тугийн" нөлөө хүндээр тусчээ. ӨМӨЗО-нд 2000 гаруй мал аж үйлдвэрийн хоршоог 152 коммун болгожээ. "Соёлын хувьсгал" нь уугуул оршин суугчдын амьдрал, эдийн засагт ихээхэн хор хөнөөл учруупав. 1947-1954 онд 1.9 сая , 1957-1967 онд 5.5 сая, 1967-1977 онд 4.6 сая мал хорогджээ. 1952-1978 оны хооронд жил бүр дунджаар 2.5 сая мал хорогдож, жилийн хорогдлын дундаж нь нийт малын 7\%-иас давж байжээ.

1978 онд болсон ХKН-ын 11 дэх удаагийн III бүгд хурлаас хойш Өвор Монголын мал аж ахуйд ч бодит өөрчлөлт гарав. 1950 онд 26 сая хоньтой байсан бол 1950-1965 оны хооронд малын тоо ойролцоогоор 70 сая (1965 онд 69 сая) болж, 2.65 дахин өсчээ. 1965-2000 оны хоорондох 35 жилд малын нийт тоо толгой 70 сая орчимд хэлбэлзэж байна ${ }^{7}$ XХ-р зууны 90-ээд онд ӨМӨЗОны хөдө० аж ахуйн бүтээгдххүний гуравны нэгийг мап аж ахуйн салбар гаргаж байжээ. 1990 оны тоо буртгэлийн мэдээгээр 48 сая маптай байжээ ${ }^{8}$. Хонь 20 сая гаруй, ямаа 8 сая гаруй, ухэр 4 сая шахам, адуу 2 сая гаруй, тэмээ 231 мянга гаруй, нийтдээ 36 сая малтай гэж зарим хүмүүс тэмдэглэжээ. Харин 1992 онд ӨМӨЗО-ны мал аж ахуй 55.5 саяд хурсэн гэсэн мэдээнд гахай, илжиг, пуус, цаа буга ч малын тоонд орсон ажээ.

Малын 56-58\% нь Ордосын ондөрлөгийн хойт болон баруун хэсэгт, тухайлбал Хөлөнбуйр, Шилийн гол, Упаанцав, Баяннуур, Алшаа зэрэг бэлчээрийн мал аж ахуй дагнан эрхэлж буй нутагт 42$44 \%$ нь газар тариалан эрхэлсэн Хянган аймаг, Ноон мөрний сав, Их хянганы хотгор, Жирэм аймгийн гол мөрний эрэг орчим, Улааншав аймгийн гол устай элсэрхэг нутаг, мал, ойн аж ахуй хоспон эрхэлдэг Их хянганы нуруу, Хэлань, Майхан уулын бүс нутаг, Шар мөрний эрэг хавийн 8 хошуу, газар тариалан, мап аж ахуй голпон эрхэлдэг Их хянганы нуруу, Түмэдийн тал, Баруун пяо голын сав, Ноон мөрний эрэг орчим байна. Ашиглаж болох бэлчээрийн талбай 66.6 сая га, бэлчээрийг тэжээпийн нөөц нь 133.6 сая тонн бөгөод хонин 
топгойлд шилжүупснээр 93.4 сая мапд хүрэлцэнэ. Өвөл, хаврын бэлчээр нь 52.2 сая га, тэжээлийн нөөц 39.6 тонн , нэг хонь өдөрт 5кг өвс иднэ гэж үзвэл бэлчээрийн талбай нь 23.6 сая (1991оны мэдээгээр-54.7 саяд) малд хүрэпцэнээ.

1979 онд мал аж ахуй эрхэлж буй 332 мянган өрх, 1 сая 739 мянган хүнээс хөдөлмөрийн чадвартай нь 545 мянган хүн байжээ. 1988 оны байдлаар 400 мян.өрх 1сая 900 мянган хүнээс хөдөлмөрийн чадвартай нь 795 мян байжээ. Мал аж ахуй эрхэлдэг бүс нутагт буй нийт хүн амын 90\% нь ӨМӨ3О-ны уугууп хүн ам болох малчин монголчууд болон бусад цөөн тоот үндэстний төлөөлөгчид юм. Өвөр монголын малчид гол төлөв хагас суурин хэлбэрээр ашиглаж, зуспан, намаржаа, өвөл-хаваржаа гэсэн гурван сууринд суурьшина. Мал аж ахуйн зохион байгуупаптын хэлбэр нь мөн $л$ хот айл бөгөөд байгал, цаг уур, малын тоо, даац гэх мэт хамааран хот айлд байх өрх, мап сүргийн тоо, бүтэц харилчан адипгүй юм. Нэг суурь нь 200-1000 толгой хонь, 50-500 орчим бодтой байна.1990ээд оны эхэн хүртэлх 40 жилд ӨМ мал аж ахуйн сапбар дотоодын хэрэгцээг оруулахгүйгээр БНХАУ-д 69.1 сая хонь, 6.7 сая үхэр, 4.1 сая адуу, 22.7 сая гахай, 1 сая 146 мян.тонн сүу, 945 мян. тонн ноос ноолуур, 150 сая бод богийн арьс буюу үнийн дүнгээр нийтдээ 138.5 милпиард юаний бүтээгдэхүун нийлүүпжээ ${ }^{10}$.

XX-р зууны 80-аад онд мап аж ахуйг шинэчлэх олон арга хэмжээг авчээ. ӨМӨЗО-ны бүх малын 95\%, нутаг бэлчээрийн гуравны хоёр хувь нь өрхийн аж ахуйд шилжсэн байна ${ }^{11}$.

1986-1990 онд малын тоо 42.5 сая /гахай орно/, VI таван жилийнхээс 3.7 сая буюу $2.8 \%$ нэмэгджээ. Төпийн хорогдоп өмнех таван жилд 5.8\% байсан бол 4.3\% болжээ. Сайн чупдрийн болон үүпдэр сайжруулсан бод, бог мал жил бүр 9.4\%-иар өсч, 22 сая болж, нийт малын 46.3\%-д хүрчээ. Упсын хэрэгцээнд жил бүр 9.3 сая топгой мал нийлүүпжээ. 53.3 мян.тонн хонины ноос, 1800 тонн ямааны ноолуур бэлтгэжэээ. ӨМӨЗО-ны хун ам тутамд жипд дунджаар 2016 кг мах, 15.2 кг сүу оногджээ. 1989 оны байдлаар хашаа барьж, хашааны бэлчээрийн талбай 2 сая 800 мян.га, таримал бэлчээр 1 сая 490 мянга, сайжруулсан бэлчээр 1сая 510 саяд хүрчээ. Бэлчээр хамгаалах тарьсан ойн зурвасын нийт талбай 70 сая га болжээ. ӨМ-д 3 сая 890 мян. өвөл-хаврын өтог бууц бүхий хороотой. Түуний 3 сая 750 мян нь тохилог дупаан саравчтай болжээ. Нийт малын $80 \%$ нь өвөл- хаврын дулаан хашаа хороогоор хангагджээ. Мап аж ахуйн сапбарыг механикжуупах ажилд ахиц гарчээ. 1990 оны байдпаар мал аж ахуй эрхэлж буй бүс нутатт жижиг оврын 
трактор 32970, өвс таригч, хаман боогч машин 19 мян, ус татах төхөөрөмж 24500, тээж боловсруупах жижиг оврын машин 47500 байгаа нь 1978 оныхоос 4 дахин их болжээ. 1992 оны байдлаар 400 мян. айл өрхийн 95 мян нь нар, салхины хүчээр ажилпадаг бага оврын цахилгаан гаргагч мотортой болжээ. Дэд бүтшийн хөгжилтэй уялдан малчдын амьдралд мэдэгдэхүйц өөрчпөлт гарав. Идэж уух, өмсөж зуүх, эдэлж хэрэгпэх, орон сууцны нехцөл дээшипжээ. Мах сүу, цагаан идээ, ногоо, жимс, ургамлын тос зэргийг өргөн хэрэглэж байна. 1990 оны байдпаар мапчдын 80\% нь өвөлжөөндөө тоосгон байшин барьж, 100 өрхийн 51\% нь зурагттай, 9.1\% нь оёдлын машинтай, 61.2\% нь дуу хураагчтай болжээ. 1991-1995 онд малын тоог 56.7 саяд хүргэн, 1990 оныхоос 6.8\% өсгех, нийт малын 55\%ийг сайн үүпдэр болон сайжруулсан үүпдрийн мал болгох, мах-680 мян.т, хонины ноос 71 мян.т, ямааны ноолуур 2400 т, сүу 550 мян. т тус тус үйлдвэрпэхээр төлөвпөж байв. Мап аж ахуйн бүтээгдэхуунн үйлдвэрлэх нийт хэмжээг 280 сая юань, малчдын цэвэр орлогыг 1300 юань, 2000 онд малын тоо толгойг 60 саяд, мал аж ахуйн бүтээгдэхүун үйлдвэрлэлийн хэмжээг 360 сая юаньд, малчдын цэвэр орлогыг 1600 юаньд т ус тус хүргэх зорилт тавьж байлаа. 2006 онд мах үйлдвэрпэл 2,5 сая тн, гахайн мах-948 мян.тн, үхрийн мах-381 мян. тн, хонины мах-847 мян.тн, ноопуур-6792 тн, хонины ноос98 мян. тн. байжээ. Бод малын тоо- 10 сая, бог малын тоо-89 сая, гахай -10 сая байв ${ }^{12}$

Өнөөгийн байдпаар 86.667 сая га бэлчээрийн талбай, туүнээс 68.18 сая га-г ашигпах бололцоотой. 1990 оны байдлаар доройтсон бэпчээрийн хэмжээ 29.92 сая га болж, ашиглаж болохуйц бэлчээрийн нийт талбайн 44\%-д хүрчээ. Цөлжилтөд 695 мян.км2 (22.97\%) хөрсний элэгдэлд оржээ. 1960-аад онд 5261 км2 байсан усан талбай 80-аад онд 3940 км2 болж 1321 км2 -аар багасчээ. 300 км2 байсан Алашаа аймгийн Гашуун нуур 1992 онд ширгэжээ. Энэ нь 2000 онд хун ам нь 18.82 сая болж, 79.24\%-ийг Хятад хүмүус эзэлж, монгопчууд 4.03 сая, нийт хүн амын $16.96 \%$ нь болжээ ${ }^{13} .2006$ онд хүн ам нь 23,923,500 болж, монголчууд 4.2 сая болжээ. Хятад хумүус ихээр суурышин газар хагапж, эмийн өвс түух зэргээр ургамлыг сүйтгэсэн нь бэлчээрийг доройтуупах том шалтгаан болжээ. Малын бэлчээрийг сэргээн сайжруулах хөтөлбөрууд хэрэгжиж байна.

Синьзян-Уйгурын Өертөө Засах Орон: Синьзян-Уйгурын Өөртөө Засах Орон нь 1.66 сая км нутаг дэвсгэртэй. Энэ нь бух Хятадын нутгийн 16.6\%-ийг эзпэх бөгөөд Казахстан, Монгол, 
Орос, Киргизстан, Афганистан, Тажикстан, Энэтхэг зэрэг 8 улстай хиллэж өөрийн орны дотор хэд хэдэн мужтай зэрэгцэн оршино. Хилийн шугам нь 5400 гаруй км байдаг нь бух Хятадын хилийн шугамын 25\% болох тул Хятадлаа хипийн шугамаар хамгийн урт, мөн гадаад орнуудтай нэвтрэх хипийн районтай. 17.7 сая хүнтэй, олон үндэстэн, ястантай. Далай тэнгисээс алс зайдуу эх газрын хуурай уур амьсгалтай. Энэ мужийн хойт хэсэг нь Аптайн нуруу, Алтан уулс сүндэрлэж, дунд талаар нь Тэнгэр ууп, оршиж Хятадын аяпал жуупчлапын нөөц ихтэй томоохон бааз нутаг болдог. Өнгөт, ховор метапл, алт, зэс, Поб нуур, калит давсны нөөц их байдаг. Дэлхийд нэрд гарсан “Торгоны зам"-ын үпэмж хэсэг нь СяньзянУйгурын нутгйг дайран гардаг байна. СУӨЗО-ны Урумчи, Ками орчмын бусад хойд хагасын нутагт хонь, ямаа, үхэр, тэмээ, адуу голпосон мал аж ахуй эрхэлнэ. СУАР нь БНХАУ-ын мал аж ахуйн таван районы нэг бөгоод нийт малын $10 \%$ нь энд байрладаг. Малыг жилийн дөрвөн улирапд бэлчээрээр малпадаг учир байгапийн бэрхшээлтэй тулгардаг. Тус районд 45 сая га тапбай малын бэлчээртэй бөгөөд шинээр бэпчээр нэмж ашиглаж байна.

СУАР-ын мап аж ахуйн 1943-1985 оны байдлыг тоймпон үзүҮпббэп ${ }^{14}$ :

\begin{tabular}{|c|c|}
\hline $\mathrm{OH}$ & $\mathrm{Man}$ \\
\hline 1943 & 14.430 .000 \\
\hline 1949 & 12.000 .000 \\
\hline 1953 & 15.430 .000 \\
\hline 1954 & 17.100 .000 \\
\hline 1957 & 20.460 .000 \\
\hline
\end{tabular}

Синьцзяны хэвпэлд малын тоо толгой /мян.топ/-1955 онд 4 029,1965 онд 4633,61978 онд $4461,9,1998$ онд 41500 болсон гэжээ ${ }^{15}$.

СУАР-ын статистикийн төвөөс гаргасан мэдээгээр 1983 онд Синьзяны малын тоо 35 сая 950 мянга гаруй толгойд хүрсэн байлаа. Малын 75 орчим хувь нь хонь, ямаа бөгоод хонины тоогоор Хятадад Өвөр Монголын дараа орно. Тус районд 1 сая ипжиг, 160 мянган сарпаг байна.

Синьзянд Хятадуудыг олноор нүүлгэн ируүпж суурьшуулахтай хопбогдон малын бэлчээрийг их хэмжээгээр хагалж байгаа нь тус автономит районы эдийн засгийн бэрхшээлт байдлыг гүнзгийрүүпэх, Хятад биш ард түмний хүн амын амьдрал доройтоход хүргэсэн 
байна. 1950 онд Синьзяны эдийн засгийн үндэс нь хөдөө аж ахуй байсан бөгөөд түүнд хүн амын 86\%, газар тариаланд 75\%, (уйгур.хотон) мал аж ахуйд 11\% (казах, монгол) ажиллаж байв. 1950 оны эхний хагаст мал аж ахуйг өсгох талаар ажлууд хийгдэв. 1955 онд эдийн засгийн болопшоог харгапзахгүйгээр хөдөө аж ахуйд өөрчпөлт хийж, хамтралжуупав. 1958 онд 85 мянга орчим өрх буюу районы нийт хүн амын 76\%-ийг нэгтгэсэн мал аж ахуйн 1716 хоршоолпыг байгуупжээ ${ }^{16}$. Мал аж ахуй дахь “өөрчпөлт" нь "их үсрэлт", "коммунчлах" явдпаар үргэлжилжээ. 1959 онд малын тоо толгойг 50 саяд хүргэхээр төлөвпөж байв. Гэвч 1960 оноос хойшхи үйл явдпууд энэ төлөвлөгөөг биепуүпэх бололцоо өгөөгуй байна. "Соёлын хувьсгал" нь СУАР-ын мал аж ахуйд ч сөрөг нөлөө узуупсэн байлаа.

Мап аж ахуйд оруулсан хөрөнгө бага байсан байсан нь хүндээр тусч байв. СУАР-д 1950-1979 оны хоорондох 29 жипд үхсэн мап 62.5 сая байгаа ба упсаас мөн хугацаанд худалдан авсан малын нийт тоо үүнээс 15.5 сая ипүу байна гэж "Миньзуяньзю" сэтгуупд тэмдэглэжээ ${ }^{17}$. 1980-аад оны дундаас хойш СУАР-ын мал аж ахуйд нааштай өөрчпөлтүуд гарч эхэлжээ. Тухайлбап, $1994 \mathrm{oH}$ гэхэд СУАР-ын нийт малын тоо 35.5 сая толгойд хурэв ${ }^{18} .1994$ оны хавар гэхэд 14 сая 839 мян.төп хүпээн авч, бүгд 43 сая 666 мянга 300 толгой мал өсгөж байлаа. 1994 онд мах үйлдвэрлэл 410 мян.т, сүүний үйлдвэрлэл 420 мян.т болжээ. Хөдөө аж ахуйн үйлдвэрпэлийн бүтээгдэхүүний хэмжээ 27 тэрбум 750 сая юаньд хүрчээ ${ }^{19} .2008$ оны эшсээр Синьцзянд 47.4 сая топгой мап байсан нь түрүу жилийнхээс 5,5\% буурсан байжээ. Махны нийт үйлдвэрпэпийн хэмжээ 1,754,900 тн болж, 9,3\% болж өсчээ. Үнээний сүу 2,090,600 тн. болж, 6,5\% өсчээ.. ${ }^{20}$ Мал аж ахуйд бэлчээр, тэжээл хүрэлцэхгуй байх, усаар гачигдах, малын өвчин, бэлчээрийн доройтол, цөлжилт, цахилгаан эрчим хүчээр хангах зэрэг салбарт тодорхой бэрхшээлүүд байсаар байна. Энд тэжээлийн баазыг өргөтгөх, бэлчээрийг хаших, тэжээлийн үйлдвэр байгуулах, сапхинаас хамгаапах ойн зурвас байгуупах, худаг гаргах (1979 онд 33 мян худаг байв) ажлууд хийгдэж байна.

Төвдийн Өөртөө Засах Орон. Төвдийн өөртөе засах орон 12 сая.км нутаг дэвсгэртэй, 2 сая хүн амтай, засаг захиргааны төв Пхас хот. Төвд улс VII зуунд уүсч, XIII-XIV зуунд дапай пам улс орны иргэний ба шашны тэргүун болсон. XVIII зуунаас далай памын засгийн эрхийг хэвээр үпдээж, манж чин упсын бүрэпдэхүүнд оржээ. Химапай, Каракорум, Кунь-Пунь, Син Төвдийн уупсаар 
хязгаарладаг. 4.5 мян.м өндөр, тэгш өндөрлөг, толгодлог тал газар ба 6-7000 м өндөр уул нурууд хосолсон байдаг. Эх газрын эрс тэс уур амьсгалтай. Тангпа, Кайлас гэх мэт нуурууд, мөсөн гоптой. Намчо, Сеппинг, Данграюм гэх мэт олон нууртай. Хайргархаг тэгш өндөрлөг, чөл, заримдаг цөл зонхипдог, гопын опон хөндийгөөр тугайн ойтой. Уул нутгийг бэлчээрт гопдуу ашигпадаг. Хүн амын 48.6\% нь Төвд үндэстэн. 1997 оны байдлаар ДНБ нь 7.698 сая хүрсэн бөгөөд үүний $70 \%$ нь хөдоо аж ахуй, аж үйлдвэрийн сапбараас орсон байна. Боловсропын сапбарт 4 их сургуупь, 106 дунд сургуупийн зэрэгцээ, хувийн 806 сургууль ажиплаж байна.

Төвдийн өөртөө засах орон бол БНХАУ-ын мап аж ахуй эрхэлдэг таван районы нэг нь юм. Байгалийн бэлчээрийн нийт хэмжээ нь 82.052 сая га буюу упсын бүх бэлчээрийн 23\%-ийг эзэлнэ. 2001 онд Төвдөд 150000 т мах, 200.000 т сүү үйлдвэрпэж, нэг хүнд 57 кг мах, 78 кг сүү ноогдсон нь дэлхийн дундаж төвшноос илүү байжээ. Төвдөд сарлаг, хайнаг, ухэр, адуу, илжиг, хонь, гахай үржүупдэг. Мап аж ахуйн бүтээгдэхуун нь Төвд хүмуүсийн амь зуулгын үндэс, хөнгөн аж үйлдвэрийн гол матерал болно. Эдгээр нь Төвдийн эдийн засагт чухал үурэг гүйцэтгэжээ. Төвдууд эрт дээр үеэс мап аж ахуй эрхэлсээр иржээ. Гэвч мал аж ахуй эрхпэх эгэл болхи нуүдпийн аж төрох ёс нь 1950-иад он хүртэл хэвээр байв. Үйлдвэрлэх хүчин нь доод түвшинд байлаа. Тоо бүртгэлийн мэдээгээр 1952 онд малын тоо толгой нь зөвхөн 9.74 сая байжээ. Өнгөрсөн хугашаанд Төвдийн мал аж ахуйд тодорхой бэрхшээлүуд гарсаар ирсэн боловч нилээд ахиц гарчээ. Үүнд: шинэ бэлчээр эзэмшиж, мапыг ус тэжээпээр хангах, өвчнөөс сэргийлэх зэрэг арга хэмжээ авчээ. Эдгээрийн үр дүнд 2000 он болоход Төвдийн нийт малын тоо 23 сая толгойд хүрчээ. Үүнд сарлаг 4 сая толгой, шар үхэр 980 000, хайнаг 270000 , үнээ 1.55 сая, адуу 140000 , хонь 11.4 сая, ямаа 5.77 сая толгой байв. Махны үйлдвэрлэл 149 300 т, суүн бүтээгаэхуүн 204000 т., хонины ноос 8609 т. тус тус хүрэв. 2008 онд Төвдед бүх төрлийн мал 24 сая толгой болсон боп 1951 онд нийт тоо топгой нь 10 сая хүрэхгүй байжээ ${ }^{21} .2008$ онд Төвдийн мал аж ахуйн ортөг 3,896,000,000 юань болж, 1959 оныхоос 5,1 дахин өсчээ. Махны нийт үйлдвэрлэл 242700 тн , сүүн бүтээгдэхуун 295200 тн болжээ.

Хох-нуур: Газарзуйн хувьд-Хох-нуур нь Төвдийн өндөрпегийн зүүн хойд хэсэгт далайн түвшнээс дээш 3000 м-ээс дээш өргөгдсөн. Нууруудын орчим нутаг далайн түвшнээс 3200-3600 м өндөрт өргөгдсөн сэруун нутаг бөгөөд 4-р сард ногоо цухуйж, 8-р сард цас 
хаялах эрс тэс цаг ууртай.

Хех нуурын район бол эртнээс нуудпийн мал аж ахуй эрхэлж байсан. Энэхуу өндөрлөг нутаг давс их. Нэг тэмээнд 300, нэг сарлаганд 200 жин давс ачдаг байна. Хех нуурын хошуу, шан бүр өвөрмөц. Давсан хошуу, давс их олборлох тул тэнд тэмээ нь сүргийн бүтшэд бусад хошууг бодвоп ипуу байдаг. Мал аж ахуйг механикжуупах асуудал их шаардпагатай. Алууг малын унапагад ихэвчлэн хэрэглэх авч, хааяа БНХАУ-ын төв хэсэгт худалдаалах явдап бас бий. Зарим нутагт хун амын 90\% нь ч мал аж ахуй эрхлэх байдап зонхилж байдаг. Одоо дунджаар өрх бүр 140, баян өрхөд 714 мап ноогдож байна.

Харин суупийн жилуудэд бэлчээрийг нилээд суурьшиптай ашиглах болсон байна. Малчин өрх бүр төвлөрсөн бэлчээрийг зөв ашиглахын зэрэгцээ тэжээл, тариаланг хавсарга болгон эрхэлж байна.

\section{ЭШЛЭЛ, 3YYПТ}

1 http:www.nationsynceleopedia.com./Asia and Oceania/Uzbekistan-avim...3/15/2007

${ }^{2}$ Батцэцэг.Ч.,ОХУ-ын БНБуриадын Упс.УБ., 1996.т.34

3 Тува за 80 пет. Кызыл.2001. с., 11

${ }^{4}$ мөн тэнд.с. 14

${ }^{5}$ мен тэнд. с. 28

${ }^{6} \mathrm{M}$ Мн тэнд.с.53

${ }^{7}$ мөн Тэнд с. 55

${ }^{8}$ OYC. 2005.N• 4., T. 130

${ }^{9}$ Өвор монголын мал аж ахуй/1984-1993/ N• 5

${ }^{10}$ Манай улсын мал аж ахуйн эхбаяпаг хийгээд орон хуваариал. Хех хот.1987.т. 155

11 Өвормонголынмал аж ахуйн тойм.Хеххот.1991.т.114 T. 116

12 М.Хасбагана.Мал аж ахуйн хамаралт. Шилийн гол.1988.

13 “Өнөөгийн Хятал", УБ., 2007.N•1.,т.17

14 OY.C.2004.N• 3.T.102-115

15 The kazakhs of Chinaessays on an EthnicMinority6 Linda Benson and Ingvar Svanberg.p81

${ }^{16}$ Синьцзян Китая. Изд-во. Чжоу Гуанбао. 1999,т.42 УБ., 1978.т. 60

${ }^{17}$ БНХАУ -ын үндэстний районууд дахь маогийнхны бодлого.

${ }^{18}$ Миньцзу Яньцзю 1982.ํ 2.т.6-12 
19 Современный Синыцянн и его место в Казахстанских и Китайских отношениях.А., 1977. с.121

20 Современный Синьцзян и его место в Казахстанскихи Китайских отношениях.А., 1977. с.121

21 "Хятал:Синьцзяны бодит байдал,тоо баримт-2009. Бээжин. 2009. 72-p $\operatorname{Tan}$

22 “Төвд: Эдийн засаг,нийгэмийн хөгжипийн иптгэл", Бээжин 2009. т. 13 